Proceedings of the Prehistoric Society 85, 2019, pp. 115-129 (C) The Prehistoric Society. This is an Open Access article, distributed under the terms of the Creative Commons Attribution licence (http://creativecommons.org/ licenses/by/4.0/), which permits unrestricted re-use, distribution, and reproduction in any medium, provided the original work is properly cited.

doi:10.1017/ppr.2019.4 First published online 10 June 2019

\title{
Re-integrating Archaeology: A Contribution to aDNA Studies and the Migration Discourse on the 3rd Millennium BC in Europe
}

\author{
By MARTIN FURHOLT ${ }^{1}$
}

Since aDNA research suggested a marked gene influx from Eastern into Central Europe in the 3rd millennium $B C$, outdated, simplistic narratives of massive migrations of closed populations have re-appeared in archaeological discussions. A more sophisticated model of migration from the steppes was proposed recently by Kristiansen et al. As a reaction to that proposal, this paper aims to contribute to this ongoing debate by refining the latter model, better integrating archaeological data and anthropological knowledge. It is argued that a polythetic classification of the archaeological material in Central Europe in the 3rd millennium reveals the presence of a new complex of single grave burial rituals which transcends the traditional culture labels. Genetic steppe ancestry is mainly connected to this new kind of burials, rather than to Corded Ware or Bell Beaker materials. Here it is argued that a polythetic view on the archaeological record suggests more complicated histories of migration, population mixtures and interaction than assumed by earlier models, and ways to better integrate detailed studies of archaeological materials with a deeper exploration of anthropological models of mobility and social group composition and the molecular biological data are explored.

Keywords: aDNA, migration, single grave burials, mobility, Corded Ware, Bell Beakers

The last few years have seen a resurgence of migration as an explanatory model for cultural change in prehistory, sparked by recent aDNA research, which showed several marked changes in the European gene-pool, among others in the 3rd millennium bc (Brandt et al. 2013; Haak et al. 2015; Allentoft et al. 2015; Olalde et al. 2018). However, the aDNA data have not so far been connected to the archaeological record in a manner that would reflect the conceptual discussions and the state of the art of the 21st century (eg, Jones 1996; Shennan 2000; Burmeister \& Müller-Scheeßel 2006; Roberts \& Vander Linden 2011). Instead, old models derived from the early 20th century which, although utterly deconstructed on a theoretical level, are still popular in much of archaeological daily practice, were picked, and thus revitalised to make sense of the data.

\footnotetext{
${ }^{1}$ Department of Archaeology, Conservation and History, University of Oslo, P.O Box 1019, Blindern, N-0315 Oslo, Norway. Email: martin.furholt@iakh.uio.no
}

These old models treat archaeological units of classification as representing distinct and closed groups of people and biological populations (as criticised by Müller 2013; Hofmann 2015; Vander Linden 2016; Ion 2017; Furholt 2018a).

In line with the traditional concepts of Gustaf Kossinna (1919) and Gordon Childe (1929) these units, called 'archaeological cultures' are seen as distinct, brick-like entities of material culture, classified in a monothetic way, that is, defined by traits that are supposed to be present in all individuals of a unit. David Clarke suggested the alternative of a polythetic classification (Clarke 1968), in which the different traits can be unevenly and incoherently distributed among different units. A unit would thus be defined by a frequent but variable co-occurrence of a set of traits present in its individuals, not excluding their occurrence in other units. Polythetic classification is a much more realistic method because, when it comes 
to social phenomena, real monothetic units almost never exist (Eggert et al. 2012, 190). For example, a pottery style with a certain regional distribution might be - and in reality mostly is - connected to more than one tradition in tool production, house building or burial ritual (Furholt 2008b; 2009). However, while Clarke's criticism was acknowledged (eg, Lüning 1972; Müller 2001), the mainstream of prehistoric archaeologists working in Europe, with only a few notable exceptions (Müller 2001; Vander Linden 2006; Furholt 2008b; 2009), still largely stick to units of classification that are conceptualised as monothetic blocks, even though they are - in most cases - only pseudo-monothetic in nature (Furholt 2012). Most colleagues will argue that monothetic units are just easier to handle (eg, Lüning 1972), while a polythetic classification creates fuzzy units.

However, we run into serious problems when we lose sight of the flawed nature of this practice, as it has happened in the recent boom of aDNA work. Here, 'the Yamnaya' and 'the Corded Ware' (Haak et al. 2015; Reich 2018) are repeatedly referred to as distinct groups of people, assuming a monothetic structure regarding the burial rituals, pottery styles, subsistence strategies, and social identities and biological proximity. This has led to a stark mis-conceptualisation of the migration processes inferred from the new aDNA data.

The polythetic classification better represents the fact that group membership is multi-dimensional and might have, in itself, a polythetic structure, that people might relate to a whole set of different social collectives (Hansen 2003), or communities of practice (Wenger 1998). For example, the realm of burial rituals might be connected to a different social collective than the realm of other activities, including the practice of pottery manufacture. These collectives, or communities of practice, do not have to be congruent, a fact that is obscured when using a monothetic classification model.

What is more, even when one uses a polythetic classification to account for the multi-dimensionality of social identities, or social group affiliations, the anthropological record suggests that people have the possibility to change their group affiliations, create new or join already existing social groups (eg, Cameron 2013). Such a fluidity of social groups can show a wide range from more to less open and intermixed settings (eg, Hillier \& Hansen 1984; Schachner 2012) but it is a widespread phenomenon in state-less societies, and archaeological and scientific data have pointed to several Neolithic local communities being composed of individuals with diverse social backgrounds (that is, areas of origin, mobility patterns, diets, see Bentley 2007; Zvelebil \& Pettitt 2013; Brandt et al. 2014; Hachem \& Hamon 2014). This is a cautionary tale for the association of archaeological units - be they polythetically of monothetically classified - with specific, clearly circumscribed groups of people.

Nevertheless, in this paper I want to point out the heuristic advantages of a polythetic perspective on the archaeological material of the 3rd millennium BC. I will argue that this will provide a more differentiated picture which is better suited to capture the dynamics of social processes connected to human mobility and social group composition. This perspective results in the definition of a new complex of burial rituals emerging in the 3rd millennium $\mathrm{BC}$, which is connected to different styles of material culture and shows the strongest affinity to individuals with genetic steppe ancestry. This is seen as a contribution to the ongoing debate about migration narratives, which has evolved around the aDNA data. I will discuss the model proposed by Kristiansen et al. (2017) and propose modifications based on the polythetic perspective advocated here.

\section{A POLYTHETIC CLASSIFICATION OF 3RD MILLENNIUM EUROPEAN ARCHAEOLOGICAL MATERIALS}

To rectify several misconceptions lying at the basis of the aDNA based migration narrative, a polythetic approach to the connection between material culture styles (mainly pottery, weapons, and tools), and burial forms dramatically changes the picture. The prevailing monothetic culture classification suggests that the two main units, the Corded Ware and Bell Beaker 'Cultures', have their own distinct burial rituals (Fischer 1956). Textbook characterisations (eg, Behrens 1973; Strahm 2010) suggest that 'the Corded Ware burial ritual' is basically single burials under burial mounds with west-east orientation of crouched burials and a gender-based differentiation (males: right side, head to the west, females: left side, head to the east). Male graves are associated with weapons (battle-axes and axes).

By contrast, Bell Beaker burials are - so the textbook narrative continues - single burials in crouched positions with a gender differentiation, but oriented north-south, (females: right side, males: left side). Male graves are associated with weapons (daggers, arrowheads, and wristguards). Told like this, it seems as if those two 'cultures' really are characterised by 


\section{Furholt. aDNA STUDIES \& MIGRATION DISCOURSE, 3RD MILLENNIUM BC IN EUROPE}

diametrically opposed, different burial forms. This view, however, overlooks a large bundle of shared characteristics: single burials, strict orientation rules and gender differentiation, the central role of weapons in male graves and drinking vessels (beakers) in general. Only in the details do the two 'groups' diverge, namely the choice of orientation and the choice on which side to rest the dead according to their gender. Even more importantly, the textbook characterisation is a stark simplification of the actual empirical data, which are much more variable. The burial customs described for the Bell Beakers only hold true in Central Europe, the Netherlands, and the British Isles (excluding Ireland). Even here orientation rules vary (eg, no standardised orientation in the north of the British Isles and the Netherlands, burial mounds are not present in all regions: Vander Linden 2006, 160f). On the Iberian Peninsula, in Italy, the largest parts of France, and Ireland, Bell Beaker materials are mostly found in other kinds of grave types (eg, megalithic graves, in collective graves, and cave burials). In Denmark, Bell Beakers are mainly found in settlements (Sarauw 2007), while in the Hungarian Csepel Group, cremation burials are frequent (Vander Linden 2006, 61).

Burials connected to Corded Ware materials are also much more variable then the textbook version suggests (Dornheim et al. 2005; Furholt 2014). In some regions the pattern described is prevalent (Jutland, most of Germany, Austria, Bohemia, parts of southern Poland). However, in other regions we find regular deviations from the textbook pattern. Gender differentiation is missing (parts of central and southern Germany, the Baltic states), reversed (southern Sweden), orientation is variable (the Netherlands), or north-south orientation prevails (southern Poland, Moravia, the Russian Fatyanovo group). In some regions Corded Ware materials are found often, or even dominantly, in megalithic graves (Danish Isles, north-east Germany). Even in those regions, in which the textbook division between Corded Ware and Bell Beaker associated burial rituals apply overall, it is possible to point to considerable overlaps and 'mixture' (see, for instance, Großmann 2016).

This is a situation much better characterised by applying a polythetic classification. In many regions burials connected with Corded Ware look very similar to the textbook Bell Beaker burials, with a dominant north-south instead of west-east orientation, or with a reversed gender-specific body placement. In addition, many Early Bronze Age 'cultures' directly following Corded Ware and Bell Beakers, such as the Unětice, Mierzanowice, or Nitra in Central Europe, the Nordic 'Late Neolithic' and Early Bronze Age in southern Scandinavia, or Wessex have also very similar burial rituals. All the burials connected to these different 'archaeological cultures' are basically variations over a common theme: highlighting the gendered individual; the association of weapons with males; the burial in a flexed position on their side; in or under kurgan-like burial mounds; and distinct rules of orientation and body placement. Drinking vessels are also a prominent grave good, be they Corded Beakers, Bell Beakers, or Bronze Age cups. There is regional variation as to how the rules are specifically executed and, in some regions, some of the elements are lacking (eg, the gendered deposition, strict orientation rules, the burial mound), while others are added (eg, stone cists), but these are regional specifics that are not restricted to burials connected with materials of one specific archaeological culture.

Thus, from a polythetic perspective when looking at burial rituals and styles of material culture, it is much a more stringent practice to identify the burials just discussed - the single burials of the Late Neolithic and Early Bronze Age periods (2900-1400 BC) in Central Europe, southern Scandinavia, the Netherlands, and the British Isles - as one overall unit of burial forms, which is much more distinct from previous, neighbouring, and following burial forms than there are differences between these graves, or between the graves connected to different archaeological cultures.

\section{THE SGBR COMPLEX}

Instead of seeing the 3rd millennium BC in Europe through the lens of monothetic, distinct archaeological cultures, each with their own specific set of burial ritual, the polythetic perspective reveals a wider complex of new elements of burial ritual transcending the borders of these entities. This is a complex of burials that highlights individual interments, gender differentiation, male warriors, and mostly strict rules of orientation of the dead (Fig. 1), as opposed to the mainly collective burials of the preceding periods and neighbouring regions. I would like to name it the 'Late Neolithic and Early Bronze Age Single Grave Burial Ritual Complex' (SGBR). SGBR appears in Central Europe and southern Scandinavia around 2900 BC, arrives on the British Isles a few hundred 


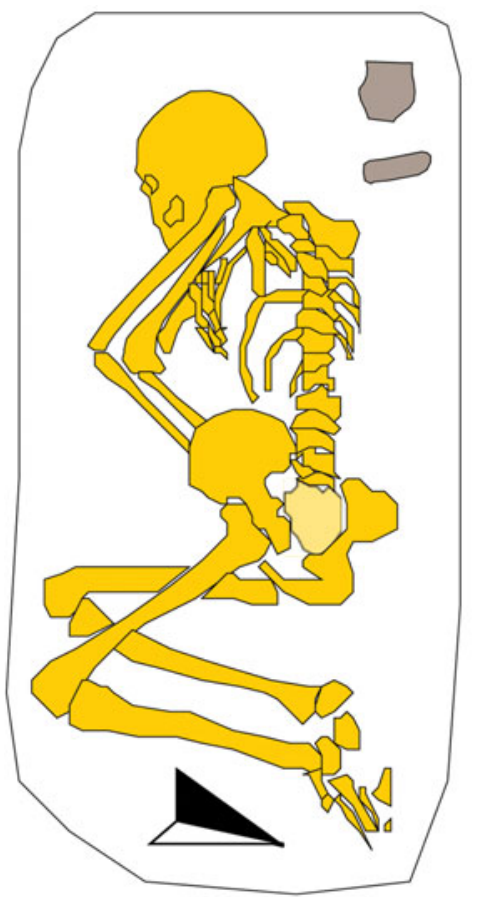

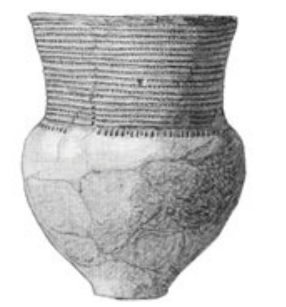
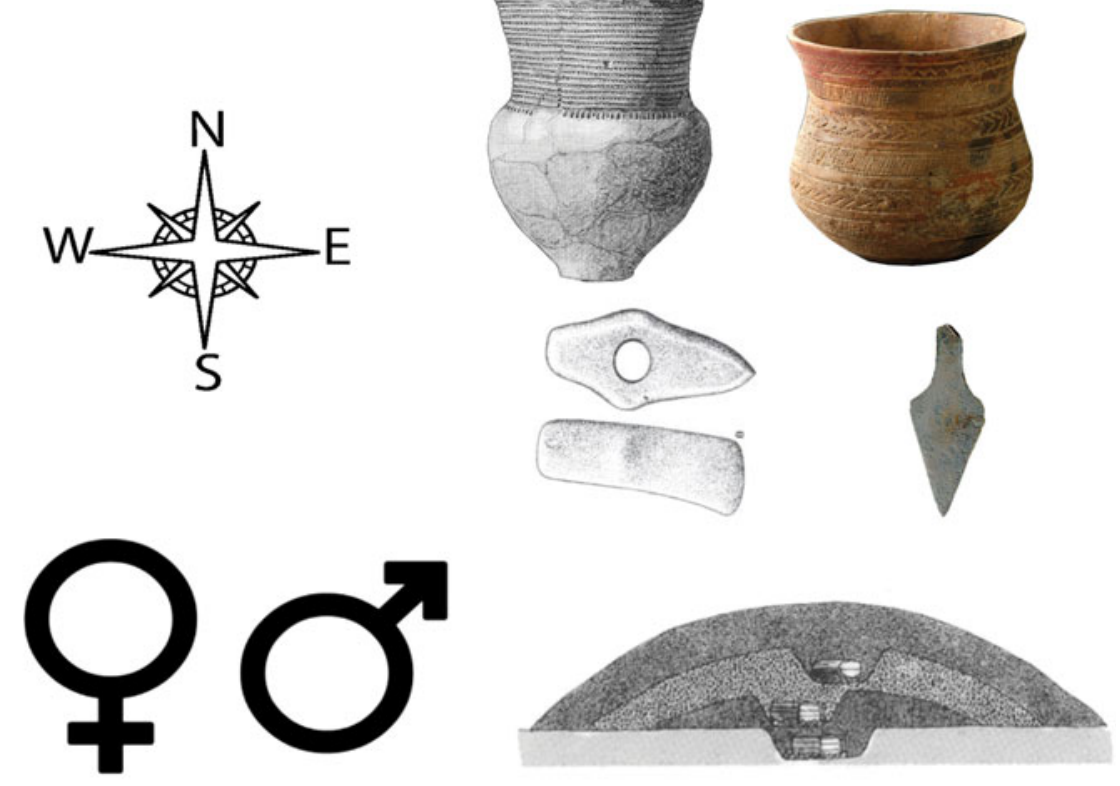

Fig. 1.

The main elements of the SGBR: Single burial in crouched position, strict orientation rules, gender differentiation by body placement, burial mound, prominence of drinking vessels, prominence of weapons in male graves

years later, and prevails until cremation burials take over, somewhen after 1400 BC.

In defining such a complex, it seems important to try to avoid a renewed reification. Explicitly, SGBR denotes a set of principles connected with burials, which are both variable and connected to different types of material culture and, most probably, different economic systems and social groups. In the beginning, burials subsumed under SGBR are connected to Corded Ware materials (Fig. 2), but a few centuries later, other styles of material culture (Bell Beakers and the different Early Bronze Age materials) become more popular (Fig. 3). Furthermore, Corded Ware pots and weapons, Bell Beakers and associated equipment, as well as Early Bronze Age things are found in other contexts than SGBR graves, namely in megalithic monuments, caves, or in settlements - often also in regions where there are no, or only very few, SGBR graves (see Figs 2-3).

\section{THE SIGNIFICANCE OF SGBR}

\section{IN THE MIGRATION DEBATE}

The identification of this distinct complex of burial forms is of special significance because it is these graves that are most strongly associated with the biomolecular finding of steppe ancestry, much more so than Corded Ware or Bell Beaker material objects. The latter are, in some regions and periods, regularly and predominantly connected to SGBR but, in others, they are found in burials of different traditions, or predominantly in settlements. As Olalde et al. (2018) have shown, steppe ancestry is predominantly connected to SGBR with Bell Beaker materials in Central Europe, the Netherlands, England, and Scotland, while in Spain, Portugal, and Italy SGBR is uncommon and most individuals show no or very little steppe ancestry. Some individual burials deviate from this pattern (eg, Petit Chasseur in Switzerland) but the trend is clear. In addition, several of the few incidences of steppe ancestry in Spain and France are connected to at least some elements of SGBR (eg, in El Virgazal: Olalde et al. 2018, I5665; La Magdalena: Olalde et al. 2018, I6471; La Fare: Olalde et al. 2018, I2575).

In the case of burials connected to Corded Ware we find a similar pattern. Most obviously, there is a clear difference between regions in which Corded Ware materials are found in SGBR graves and those in 


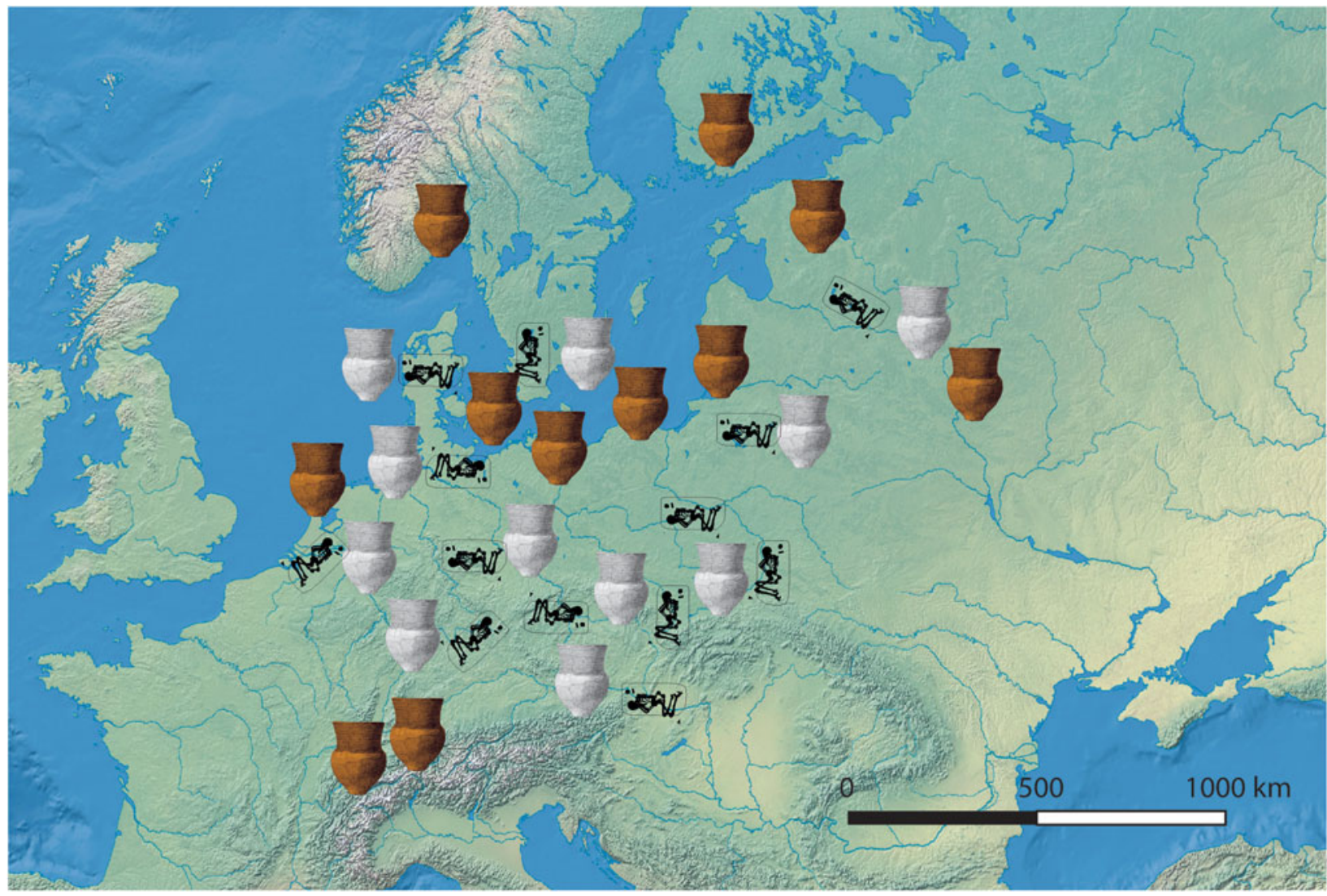

Fig. 2.

The early SGBR in Europe around 2700 BC (skeleton symbols). In addition, the map shows the regional patterns of Type 1 (grey Corded Ware beaker symbols) and Type 2 (orange Corded Ware beaker symbols) Corded Ware

which they are found in settlements (see Furholt 2014). Interestingly there is a real inversion between those two types of regions with Corded Ware materials. In the first group, that is central and southern Germany, Lower Austria, Bohemia, Moravia, southern Poland, the Netherlands, north-west Germany and Jutland, and parts of the Baltic states: Strahl 1990; Strahm \& Buchvaldek 1991; Rimantienè 1992; Šebela 1999; Buchvaldek et al. 1997; Matthias 1982; Dresely 2004; Hübner 2005; Włodarczak 2006; Furholt 2014), there are thousands of SGBR graves, while settlements with Corded Ware materials are found very rarely. By contrast, in those regions where Corded Ware materials are frequently found in settlements, there are no, or very few, SGBR graves, as in Switzerland (Strahm 1971; Hafner \& Suter 2003), the Baltic states coastal areas (Rimantiene 1992), Belarus (Charniauski 2011), Finland (Nordqvist \& Häkälä 2014), southern Norway (Prescott \&
Glørstad 2015), or coastal Netherlands (Beckerman 2015). Corded Ware materials found in settlements are almost always from situations where they are successively integrated into previously existing settlement structures and styles of material culture (eg, in coastal Netherlands, western Switzerland, the Baltic states, and Belarus), or where they at least build upon existing traditions (eg, eastern Switzerland and Finland). Additionally, there are regions where Corded Ware materials are found in non-SGBR - megalithic - graves graves and very rarely in settlements, as in north-east Germany (Jacobs 1991) and on the Danish Isles (Iversen 2015). The Fatyanovo Group on the Russian plain seems to be an exception showing an abundance of both SGBR graves and settlements (Artemenko 1987).

What is subsumed under 'Corded Ware', then, are obviously very different social phenomena. On the most general level it makes sense to differentiate 


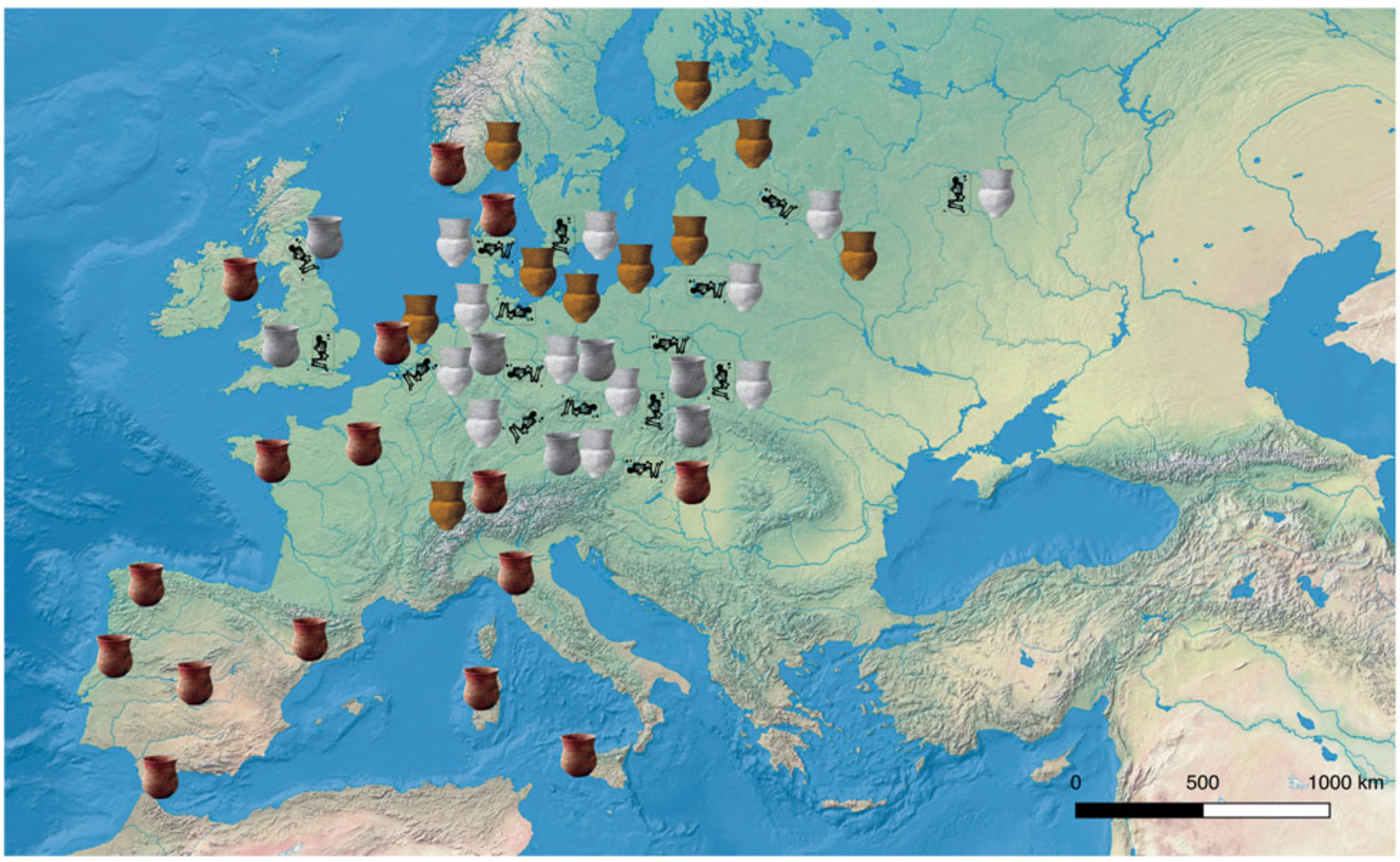

Fig. 3.

SGBR in Europe around 2400 ВC (skeleton symbols). In addition, the map shows the regional patterns of Type 1 (grey Corded Ware beaker symbols) and Type 2 (orange Corded Ware beaker symbols) Corded Ware and Bell Beaker material culture associated with SGBR (grey Bell Beaker symbols) and not associated with SGBR (brown Bell Beaker symbols)

between 'Type 1' Corded Ware (Corded Ware in SGBR graves) and 'Type 2' Corded Ware (Corded Ware in settlements, without SGBR). In Type 1 Corded Ware graves, we consistently find individuals with steppe ancestry, in Type 2 Corded Ware contexts there are almost no connected burials from which to draw. Clearly, absence of evidence is not evidence of absence, but the situation regarding Corded Ware is consistent with the Bell Beaker pattern: genetic steppe ancestry is strongly connected to SGBR burials. When it comes to the northern European megalithic graves, these are mostly connected to pre-Corded Ware archaeological units. Most burials show a presteppe-impact genetic profile (Skoglund et al. 2012; 2014; Malmström et al. 2015), a few recently published individuals from the later part of the $3 \mathrm{rd}$ millennium also show steppe impact (Rascovan et al. 2018).

Yet, overall steppe ancestry is most strongly connected to SGBR type burials. As SGBR shows parallels with the burials connected to steppe-based complexes like Sredni Stog, Usatovo, and Yamnaya, ie, the single burial under a kurgan and some form of rules for orientation of the dead (Frînculeasa et al. 2015), the connection in the biological ancestry is paralleled by connections in burial ritual.

\section{CONSEQUENCES: A SAMPLING BIAS?}

If the biological steppe ancestry is connected to a specific complex of new burial forms, the SGBR, then there arises a problem. Sampling for aDNA requires well-preserved burial materials from secure contexts, which SGBR burials provide, unlike other contexts. It is most likely that many other burial forms are archaeologically invisible, such as those connected to the southern Central European Late Neolithic associated with units like Cham, Horgen, Řivnáč, Jevišovice $\mathrm{B}$, or Bošáca), while poor bone preservation in the majority of northern European megalithic 


\section{Furholt. aDNA STUDIES \& MIGRATION DISCOURSE, 3RD MILLENNIUM BC IN EUROPE}

graves creates a further sampling bias. If SGBR represents a new form of burial ritual, directly connected to migrants and their lineages, the local, native populations will probably be under-represented in the aDNA record. Thus, speculations about the total or near total extinction of the Neolithic populations in Central Europe after the arrival of migrants deriving from the steppes (Haak et al. 2015) would be exaggerated. As SGBR burials remain dominant in the archaeological record until the end of the Early Bronze Age, and the cremation burials that follow provide less favourable conditions for aDNA sampling, the genetic composition of later individuals from the Iron Age should be taken into account, to assess if we have, so far, missed a non-steppe 'shadow population' in the 3rd and 2nd millennia BC. Further aDNA sampling of non-SGBR burials from this latter period will also shed more light on this issue.

\section{DISCUSSION: A REFINED MODEL OF POPULATION MOVEMENT IN THE 3RD MILLENNIUM}

Recently, Kristiansen et al. (2017) presented a model to explain the $3 \mathrm{rd}$ millennium migration process. They propose migration of mostly male individuals associated with Yamnaya burials into eastern Europe, mixing with local females, from where again mainly males migrate into central Europe mixing with local females, thus creating Corded Ware. The theory of a predominantly male migration in the $3 \mathrm{rd}$ millennium $\mathrm{BC}$ is debated in aDNA research (Goldberg et al. 2017; Lazaridis \& Reich 2017). Still, the archaeological and osteological evidence shows that eastern Central European Yamnaya and early Corded Ware burials are dominated by male individuals (Furholt 2014; Frînculeasa et al. 2015). This model is a good starting point to better understand processes of human migration in the 3rd millennium but here I want to criticise its monothetic conceptualisation of 'archaeological cultures'. Steppe ancestry is not necessarily solely connected to individuals from a Yamnaya-related context (as also clearly stated by Kristiansen et al. 2017, 335). Yamnaya burials just happen to be the group of Eastern European burials first targeted by, and most readily available to, geneticists. In addition, as with Corded Ware and Bell Beakers, Yamnaya is also not likely to represent one unified social group or biological population. As Heyd (2017) points out, steppe-related characteristics of burials have been coming from the east into South- eastern and Central Europe for many centuries before Yamnaya.

The label 'Yamnaya' thus refers to a number of different burial rites, associated with a number of different types of material culture. Also, it does not necessarily represent all possible sources of the new genetic component which appears in Central Europe during the 3rd millennium. In Kristiansen's model the label 'Yamnaya' should thus - in line with what is currently discussed in the wider archaeological and archaeogenetic community (Eisenmann 2018) be replaced by 'people with steppe ancestry' or 'Eastern European Ancestry' and, for the reasons discussed above, 'Corded Ware' should be replaced by 'SGBR'.

The whole notion of Yamnaya as representing nomadic pastoralists (Anthony 2007, 321f.; for a critique of the pastoralist concept, see Makarewicz 2013) and this being transferred to Corded Ware in Central Europe is problematic. We are only starting to get an empirical understanding of the actual economic and social strategies connected to the different people buried in Yamnaya graves (Shishlina et al. 2012). So far, pastoralist strategies appear to have been practised in combination with the exploitation of other food sources by some segments of the population (Shishlina 2008; Gerling et al. 2012). Conditions for herding are quite varied in different parts of Central Europe and it seems that subsistence strategies vary in connection to different Corded Ware regions (Dörfler \& Müller 2008).

Cultural traditions and social systems are likewise to be seen as regionally diverse. Closer inspection of what is normally called 'Yamnaya kurgans' - allegedly reflecting Yamnaya ideology (Kristiansen et al. 2017) - has clearly revealed a much more complex relation between local and immigrant individuals, burial rituals, and material culture. For example, Gerling et al. (2012) report on their detailed analyses of the Yamnaya burial mound of Sárrétudvari-Ốrhalom in eastern Hungary. The earliest burial here is not the expected male steppe migrant but a female (laid down in a non-Yamnaya fashion before $3100 \mathrm{BC}$ ) with local strontium values. The next burial (before $2900 \mathrm{BC}$ ) is a mature male, also with local strontium signals, laid down west-east on his right, with ochre and cattle and horse bones - features that can be associated with steppe region burials. This is followed by a group of four non-local men and one child (buried partly in Yamnaya fashion between 2900 and 2500 BC). 
Their isotope signatures and some grave goods point towards Transylvania, while other grave goods point towards both the Pontic Steppes and the Balkans. This is referring to a complex history, to a merging of local and regional connections by people with diverse regional origins and mobility patterns. The narrative of Yamnaya males migrating westwards severely undervalues the complexity of processes indicated by this single burial mound.

There are more studies of mobility and social group composition in the 3rd millennium in Central Europe, but like the Sárrétudvari-Őrhalom case, isotope data are mostly referring to burial ground populations rather than settlement communities. But here too, as in the Early Neolithic (see above), differences in diet and mobility patterns on the same burial grounds, as well as between them, are clearly visible (Haak et al. 2008; Sjögren et al. 2016; Knipper et al. 2017). The three studies cited refer to central and southern German burial grounds and, in all cases, a higher degree of non-local $\mathrm{Sr}$ isotope values in female individuals is interpreted as the result of virilocal exogamous marriage/mating practices. This is a valid conclusion. However, it seems unsatisfactory to take one undifferentiated model female exogamy - as a sufficient explanation for the data patterns. This model leaves unexplained the nonlocal males in all three studies or the lack of offspring that can be connected to the incoming women found in in the Lech valley by Knipper et al. (2017). This latter finding increases the significance of the Eulau grave 98, where the supposed mother of the two children in this triple burial is definitely not the biological mother (Haak et al. 2008, 18228). An exchange or circulation of children might also be a viable explanation.

Talking about female exogamy may be helpful to a certain degree but only if it goes beyond mere labelling. Otherwise it functions as a means to divert us from a further discussion about social organisation. While female exogamy is a sign of fluid social group boundaries, it often seems to serve the opposite purpose of diverting attention from this very fact and downplaying all other visible forms of mobility. It seems to serve as a final explanation and allows us to hold onto the view of clearly circumscribed social groups, as it is 'only' women who are handed over across stable social borders by supposedly male actors. It is telling that the non-local males in Sárrétudvari-Örhalom are never discussed as cases for male exogamy.

In the same way, while the finding of a male-dominated migration from the steppes into Europe is compelling (Goldberg et al. 2017), it does not actually suggest that only men are responsible for the change in the genetic record and should not lead us to a 'case closed' mentality concerning migration processes (see Lazaridis \& Reich 2017). Both these findings male-dominated migration and the fact that more females were mobile - are also somewhat contradictory, suggesting that more complex processes were at play. In any case it is not sufficient to argue at a scale level which suggests the same processes or factors as being responsible for the creation of all the different social phenomena we associate with Yamnaya, Corded Ware, or Bell Beakers.

Returning to the model of Kristiansen et al. and starting from the archaeological material, the polythetic approach propagated here strongly suggests as a first step - a differentiation of what features as 'Corded Ware'. In the regions dominated by SGBR graves - that in the beginning are associated with Corded Ware materials (Type 1 Corded Ware, see Fig. 2) - we may be dealing with forms of colonisation, bringing about a profound social transformation. Here the appearance of genetic steppe ancestry coincides with the formation of this new burial complex, which highlights the gendered individual and also shows the importance of weapons in connection to male individuals. Recently, Robb and Harris (2018) have argued that we actually see the formation of the ideological emphasis on binary gender identities, which was much less pronounced in the previous periods, but which has more or less prevailed, they argue, until today in western Eurasia, where it hence dominates our thinking. Kristiansen et al. (2017) suggest that this fundamental redefinition of human identities is to be connected with the dominance of male migrants in the 3rd millennium (see above). However, it is worth noting that in the 3rd millennium we are first and foremost dealing with a phenomenon salient in the burial ritual of the SGBR. The wider implications of this emphasis on binary gender roles is a topic that goes beyond this paper.

These SGBR graves are found in regions with only sparse evidence of previous populations (like in Jutland; see Hübner 2005), or in previously settled regions (Netherlands, central Germany, Bohemia, southern Poland, parts of southern Germany, Lower Austria). In these latter regions, Corded Ware material culture is also found relatively often in settlement sites assigned to the preceding (yet chronologically overlapping) Late Neolithic units (ie, Funnel 


\section{Furholt. aDNA STUDIES \& MIGRATION DISCOURSE, 3RD MILLENNIUM BC IN EUROPE}

Beakers, Wartberg, Vlaardingen, Cham, Řivnač, Jevišovice B, etc; see Furholt 2008a). Most material things classified as Corded Ware are object types which first appear in different parts of Central Europe (the Corded Beaker) or southern Scandinavia (the Corded Ware Battle Axe), or can be traced back to central European traditions (the Amphorae, which resemble the slightly earlier Globular Amphorae in eastern Central Europe; see the discussion in Furholt 2014). These different components are merged together over time, most visibly in the SGBR graves. It seems important to stress that they are not traditions that can be traced to the eastern European steppe region. Still, as Corded Ware material culture appears in the earliest SGBR graves, they are indirectly connected to individuals with a strong genetic steppe ancestry, that is migrants and their offspring.

As we have to assume that pottery is mostly locally made (Strien 2005; Pechtl 2015; Müller \& Peterson 2015; Vander Linden 2015; Maggetti \& Suter 2017), the presence of Corded Ware pottery in settlements dominated by 'pre-Corded Ware' pottery styles that are located in or close to regions with SGBR graves, is likely to also represent some form of mixing or, at least, co-habitation of individuals with a strong steppe ancestry component in their family tree and individuals with a stronger Central European ancestry. By 2600 BC most of these traditional settlement sites are abandoned and settlement is now of the new, archaeologically relatively invisible, kind which is characteristic for regions with Type 1 Corded Ware. Settlements being archaeologically invisible might be interpreted as a result of a light, mobile architecture, connected with steppe traditions of mobile pastoralism (Anthony 2007). Yet, we have to acknowledge that the scarce settlement material we do have from these regions actually does show regional variability, often resembling regional traditions (Hansen 1986; Kossian 2004; Hecht 2007; Dörfler \& Müller 2008). Thus it is too easy - and methodologically incorrect - to define scarcity of settlement remains as a similar cultural trait adopted from the steppe regions. Archaeologically, what we see in the regions with Type 1 Corded Ware is a mixing of regional and transregional traditions (settlement patterns, material culture), into a situation where the transregional traditions successively, and relatively quickly (4-10 generations between roughly 2800 and $2600 \mathrm{BC}$ ) become dominant. This mixing of cultural traditions might have been driven by a biological mixture, in which female exogamy played its role, beside other mechanisms, for example exchange of children, as the Lech valley (Knipper et al. 2017) and Eulau (Haak et al. 2008) cases suggest, or a higher degree of social fluidity in general.

The processes leading to the formation of situations represented by Type 2 Corded Ware seem to be very different. Here, it seems that the local communities living in the traditional settlements successively adopted Corded Ware pottery and battle-axes. We have to be careful to separate the realm of pottery production, whose traditions are created via social learning, people`s identities, which are subjective, and their biological ancestry, which might have been largely unknown to the individuals themselves. Corded Ware pottery vessels are thus, first and foremost, part of a transregional pottery style that emerged in Central Europe between 2900 and 2600 BC. We do not know if the connection of this pottery style to the SGBR graves and people with steppe ancestry in other regions were known to the people that started to produce these vessels along with those of other, more local styles. Yet, as specific traditions in typology and technology are not randomly changed but are expressions of socially embedded practices of production and knowledge transfer (Furholt 2018b), there is a likelihood that incoming individuals might have brought these innovations, especially as they are transregionally shared. And the connection of these new traditions of pottery making to the SGBR burials in some regions might also suggest that some of these incoming individuals could have had close contact with, or themselves were people with, genetic steppe ancestry.

Even if many details remain unclear, archaeology can contribute significantly to a better understanding of these social integration processes. An excellent example of this is Sandra Beckerman's (2015) study of Dutch coastal settlements where she points to different scenarios of how the local Vlaardingen pottery style and the translocal Corded Ware pottery are intertwined. While, in some cases, Corded Ware pottery replaces Vlaardingen vessels rather abrubtly, mostly there was a side-by-side occurrence of the two styles and gradual replacement. Most importantly, in several sites Beckerman can show how different elements temper, technology, vessel shape, decoration - change over time with Vlaardingen vessels slowly adopting Corded Ware elements (Beckerman 2015, fig. 6.1). This indicates a long-lasting interaction between 
potters socialised in both traditions, be it at the Dutch sites in question or somewhere else. The different speed of transformation and the extent to which the local styles are replaced by the translocal ones (compare also, for instance, the difference between eastern and western Switzerland) might indicate the proportion of newcomers vs locals, but they could also be dependent on other factors determining the success of one style or technological tradition over the other. The exact mechanisms of change can only be explored through a detailed technological and typological study of pottery production patterns in individual sites or regions with a good control of chronological resolution, as it was done by Beckerman and as it can be done in many north-alpine lake-shore settlements.

From 2500 BC, Bell Beakers partly replace Corded Ware as the dominant material culture style used in SGBR graves in Central Europe and the Netherlands. At this time, SGBR graves appear together with Bell Beaker materials and genetic steppe ancestry in the British Isles while, at the same time, this style of material culture is not, or is only loosely, connected to genetic steppe ancestry in most parts of Western Europe (Olalde et al. 2018).

Thus, in the 3rd millennium in Central Europe, in contrast to the transregional burial rituals and pottery styles, subsistence strategies, settlement patterns, and house forms are clearly regional, often following local traditions (Hafner \& Suter 2003; Salzman 2004; Dörfler \& Müller 2008; Kleijne 2013; Brozio et al. 2013; Beckerman 2015; Brozio 2016; Suter 2017). A similar pattern is also well-documented for the different Bell Beaker regions (Vander Linden 2006).

To sum up, in the early 3rd millennium, what is really new in Central Europe is the introduction of a novel package of burial ritual activities and grave forms that can be connected with migration from Eastern Europe and is to be seen in the realm of cosmology and social relations (eg, the binary gender model) but much less so in terms of subsistence economy or material production. There are some regions in which this profound cosmological and social change is not visible at all in the archaeological record (Type 2 Corded Ware; Bell Beakers outside the SGBR burials).

\section{CONCLUSION: MODELS OF MIGRATION, FORMS OF MOBILITY?}

This polythetic view of the $3 \mathrm{rd}$ millennium indicates that the narrative of Steppe-derived migration creating
'Corded Ware Culture' and later 'Bell Beaker Societies' is misleading. What the archaeological record in Central Europe after 2900 BC shows, first and foremost, is the creation of a new complex of burial rituals (SGBR) that is connected to many different styles of material culture. The model proposed by Kristiansen et al. (2017) contains a one-dimensional way of thinking about social groups in the 3rd millennium. This is most visibly expressed in the reliance on monothetically perceived units, like Yamnaya, Corded Ware, Bell Beakers, and in likewise monothetical descriptors, such as 'migration' and pastoralism. This should be refined by integrating a more nuanced view on the archaeological materials, using a polythetic classification. Since the establishment of the simplified migration narrative, the image of a onedirectional, single-event mass migration, has caught on in most works dealing with the new aDNA data. However, we should be able to pursue more complex models.

First, the idea of neatly separated groups of migrants and groups of locals, who may or may not interact, is a false premise. As discussed above, social groups in the Neolithic are probably more fluid and group membership is more flexible than the simplified model implies. Thus, the suggestion of mixing between those labelled as 'natives' and 'locals' should not be seen as especially remarkable, or exceptional. Rather, it should remind us that what we often casually refer to as 'migration' is likely a summary term for a multiplicity of individual local and regional histories of movement, mixture, and secession, probably over many generations. To talk about 'natives' and 'locals' refers to emic self-characterisations which are neither to be equated with people's genetic ancestry which is not necessarily known, as it can be many generations old at any given point in time - nor with the material culture they produce and use - which is determined by socialisation, and subject to the flexibility and social fluidity described above.

Secondly, this view is consistent with the archaeological evidence of the 3rd millennium $\mathrm{BC}$ which shows a high degree of regional chronological variability and a polythetic setting between different kinds of materials (eg, burial rituals, pottery, tools, weapons). While many archaeologists tend to brush over both this variability and the non-congruent setting of different kinds of materials, and focus on regularities and similarities between, for instance, different Corded Ware regional groups, the evidence 


\section{Furholt. aDNA STUDIES \& MIGRATION DISCOURSE, 3RD MILLENNIUM BC IN EUROPE}

suggests that there is not one uniform migration phenomenon, but many different variants, which yield different archaeological outcomes. Thus, the definition of two types of archaeological units connected to Corded Ware should not be taken to suggest that there are exactly two distinct ways in which people migrated into Central Europe. Rather, it seems clear that the historical processes behind the formation of communities represented by Type 1 and Type 2 Corded Ware are likely to be much more varied and complicated than these types would suggest. But this still very simplified classification seems as a useful intervention in the ongoing debate of how to better understand the results of the aDNA studies by better integrating these data with the archaeological data and anthropological knowledge. Yet, to capture the complexity, multidimensionality, and variability of processes, we need to direct more attention to regional and local processes. We need more studies like, for example, Haak et al. (2008), Gerling et al. (2012), or Knipper et al. (2017), integrating both bioarchaeological and archaeological data on specific sites or in more circumscribed regions. We also have to pay more attention to the existing archaeological work unveiling the interaction of local and transregional styles of material culture (Hafner \& Suter 2003; Kleijne 2013; Beckerman 2015; Iversen 2015; Großmann 2016; Brozio 2016; Suter 2017; Kolár 2018; Schultrich 2018) even if these cannot be directly connected to aDNA analyses on the same materials.

An open and fruitful discussion between archaeologists and biologists on how to integrate both archaeological and biological knowledge requires, from both sides, a deeper understanding of the potential and limitations of each dataset. It requires that we do not blur objects of material culture, traditions of burial rituals, and patterns of biological relatedness, or genetic proximity. Instead we need to explore these as different albeit interconnected - spheres of human activity, whose patterns can only be synthesised when they have first been analytically isolated. In order to build better models with which to understand the social and biological transformations of the 3rd millennium $\mathrm{BC}$ in Europe, we need to actively turn away from the traditional monothetic approach that has proven to be detrimental, as it meshes together different aspects of social and cultural interaction with biological descent. Neither from a biological nor from a social perspective were 3 rd millennium communities homogeneous and neatly separated, an observation that requires - as a first step - a more thorough, and polythetic, approach to these different spheres of human lives. In the same vain, terms like migration, pastoralism, or female exogamy need to be further explored beyond their use as a mere label, using the broad array of anthropological knowledge, and different forms of human mobility should not be seen as mutually exclusive.

This also means that it is far beyond the scope of this paper to provide a more concrete model for the migration processes of the 3rd millennium $\mathrm{BC}$ in Europe because there is, in my view, not one single model to be set up. Instead such models should be developed based on local case studies, for which different mechanisms will apply. Such a more bottom-up perspective should complement and thus refine overall, top-down models like that put forward by Kristiansen et al. to which this paper is a response.

\section{BIBLIOGRAPHY}

Allentoft, M.E. et al. 2015. Population genomics of Bronze Age Eurasia. Nature 522(7555), 167-72

Anthony, D.W. 2007. The Horse, the Wheel, and Language: how Bronze-Age riders from the Eurasian steppes shaped the modern world. Princeton: Princeton University Press

Artemenko, I.I. 1987. Kul'tury shnurovoy keramiki: srednedneprovskaya, prikarpatskaya, gorodokskozdobickaya, stzhizhovskaya. In Arkheologiya SSSR. Epokha bronzy lesnoy polosy SSSR, 35-51. Moskva: Russian Academy of Sciences

Beckerman, S.M. 2015. Corded Ware Coastal Communities: using ceramic analysis to reconstruct third millennium $B C$ societies in the Netherlands. Leiden: Sidestone Press

Behrens, H. 1973. Die Jungsteinzeit im Mittelelbe-SaaleGebiet. Berlin: Deutsche Verlag der Wiesenschaften

Bentley, R.A. 2007. Mobility, specialisation and community diversity in the Linearbandkeramik: isotopic evidence from the skeletons. In A. Whittle, and V. Cummings (eds), Going over. The Mesolithic-Neolithic Transition in North-Western Europe, 117-40. Oxford: Oxford University Press

Brandt, G. et al. 2013. Ancient DNA reveals key stages in the formation of Central European mitochondrial genetic diversity. Science 342(6155), 257-61

Brandt, G., Knipper, C., Nicklisch, N., Ganslmeier, R., Klamm, M. \& Alt, K.W. 2014. Settlement Burials at the Karsdorf LBK Site, Saxony-Anhalt, Germany: Biological Ties and Residential Mobility. In A. Whittle, and P. Bickle (eds) Early Farmers. The View from Archaeology and Science, 95-114. Oxford: British Academy. Available at: http://www.britishacademypublications. com/view/10.5871/bacad/9780197265758.001.0001/ upso-9780197265758-chapter-6 [Accessed?]

Brozio, J.P. 2016. Megalithanlagen und Siedlungsmuster im trichterbecherzeitlichen Ostholstein. Bonn: Habelt 


\section{THE PREHISTORIC SOCIETY}

Brozio, J.P., Kirleis, W. \& Müller, J. 2013. Jungsteinzeit zwischen Haus und Freifläche - Oldenburg-Dannau LA 77. Archäologische Nachrichten aus Schleswig-Holstein 19, 25-7

Buchvaldek, M., Moucha, V., Popelka, M. \& Vojtěchovská, I. 1997. Katalogy šňroové keramiky v Čechách XI-XIV. Kladensko, Slánsko, Kralupsko a Praha-západKataloge der Schnurkeramik in Böhmen XI-XIV. Die Räume von Kladno, Slaný, Kralupy n. Vlt. und PrahaWest. Praehistorica 22, Varia Archaeologica 7, 113-255

Burmeister, S. \& Müller-Scheeßel, N. 2006. Soziale Gruppen - kulturelle Grenzen: die Interpretation sozialer Identitäten in der prähistorischen Archäologie. Münster: Waxmann

Cameron, C.M. 2013. How people moved among ancient societies: broadening the view. American Anthropologist 115(2), 218-31

Charniauski, M. 2011. Belarusian wetland settlements in prehistory. Wetland settlements in northern Belarus. In E. Prackenaite (ed.), Wetland Settlements of the Baltic. A Prehistoric Perspective, 113-32. Vilnius: Center of Underwater Archaeology. Available at: https://www. academia.edu/37345867/Belarusian_Wetland_Settlements_ in_Prehistory_Wetland_settlements_in_Northern_Belarus [Accessed November 20, 2018]

Childe, V.G. 1929. The Danube in Prehistory. Oxford: Clarendon

Clarke, D.L. 1968. Analytical Archaeology. London: Methuen

Dörfler, W. \& Müller, J. 2008. Umwelt - Wirtschaft Siedlungen im dritten vorchristlichen Jahrtausend Mitteleuropas und Südskandinaviens [Tagung Kiel 2005]. Neumünster: Wachholtz

Dornheim, S., Liessner, B., Metzler, S., Müller, A., Ortolf, S., Sprenger, S., Stadelbacher, A., Strahm, C., Wolters, K. \& Wiermann, R.R. 2005. Sex und gender, Alter und Kompetenz, Status und Prestige: Soziale Differenzierung im 3. vorchristlichen Jahrtausend. In J. Müller (ed.), Alter und Geschlecht in ur- und Frühgeschichtlichen Gesellschaften, 27-71. Bonn: Habelt, Universitätsforschungen zur Prähistorischen Archäologie

Dresely, V. 2004. Schnurkeramik und Schnurkeramiker im Taubertal. Stuttgart: Theiss

Eggert, M.K.H., Müller-Scheessel, N. \& Samida, S. 2012. Prähistorische Archäologie: Konzepte und Methoden 4., überarb. Aufl.Tübingen: Attempto

Eisenmann, S. et al. 2018. Reconciling material cultures in archaeology with genetic data: The nomenclature of clusters emerging from archaeogenomic analysis. Scientific Reports 8(1), 13003

Fischer, U. 1956. Die Gräber der Steinzeit im Saalegebiet. Studien über neolithische und frübbronzezeitliche Bestattungsformen in Sachsen-Thüringen. Berlin: de Gruyter

Frînculeasa, A., Preda, B. \& Heyd, V. 2015. Pit-Graves, Yamnaya and Kurgans along the lower Danube: disentangling IVth and IIIrd millennium BC burial customs, equipment and chronology. Praehistorische Zeitschrift 90(1-2), 45-113
Furholt, M. 2008a. Erscheinungen asynchroner kultureller Entwicklung am Übergang vom Spät- zum Endneolithikum in Mitteleuropa. Eine Untersuchung der Siedlungsfunde mit Schnurkeramik. In W. Dörfler, and J. Müller (eds), Umwelt - Wirtschaft - Siedlungen im dritten Jahrtausend Mitteleuropas und Südskandinaviens. Internationale Tagung Kiel 4.-6. November 2005, 9-34. Neumünster: Offa-Bücher 84.

Furholt, M. 2008b. Pottery, cultures, people? The European Baden material re-examined. Antiquity 82, 617-28

Furholt, M. 2009. Die nördlichen Badener Keramikstile im Kontext des mitteleuropäischen Spätneolithikums (36502900 v. Chr.). Bonn: Habelt

Furholt, M. 2012. Die räumliche Struktur der entwickelten Trichterbecherkeramik: Eine quantitative Analyse stilistischer Ähnlichkeitsmuster. In M. Hinz \& J. Müller, (eds), Siedlung, Grabenwerk, Großsteingrab. Studien zu Gesellschaft, Wirtschaft und Umwelt der Trichterbechergruppen im nördlichen Miteleuropa. Frübe Monumentalität und soziale Differenzierung, 473-84. Bonn: Habelt

Furholt, M. 2014. Upending a 'totality': re-evaluating Corded Ware variability in Late Neolithic Europe. Proceedings of the Prehistoric Society 80, 67-86

Furholt, M. 2018a. Massive migrations? The impact of Recent aDNA studies on our view of third millennium Europe. European Journal of Archaeology 21(2), 159-91.

Furholt, M. 2018b. Translocal communities- exploring mobility and migration in sedentary societies of the European Neolithic and Early Bronze Age. Praehistorische Zeitschrift 92(2), 304-21

Gerling, C., Bánffy, E., Dani, J., Köhler, K., Kulcsár, G., Pike, A.W.G., Szeverénvi, V. \& Heyd, V. 2012. Immigration and transhumance in the Early Bronze Age Carpathian Basin: the occupants of a kurgan. Antiquity 334, 1097-111

Goldberg, A., Günther, T., Rosenberg, N.A. \& Jakobsson, M. 2017. Ancient X chromosomes reveal contrasting sex bias in Neolithic and Bronze Age Eurasian migrations. Proceedings of the National Academy of Sciences 114(10), 2657-62

Großmann, R. 2016. Das dialektische Verhältnis von Schnurkeramik und Glockenbecher zwischen Rhein und Saale. Bonn: Habelt

Haak, W., Brandt, G., de Jong, H.N., Meyer, C., Ganslmeier, R., Heyd, V., Hawkesworth, C., Pike, A.W.G., Meller, H. \& Alt, K.W. 2008. Ancient DNA, Strontium isotopes, and osteological analyses shed light on social and kinship organization of the Later Stone Age. Proceedings of the National Academy of Sciences 105(47), 18226-31

Haak, W. et al. 2015. Massive migration from the steppe was a source for Indo-European languages in Europe. Nature 522(7555), 207-11

Hachem, L. \& Hamon, C. 2014. Linear Pottery Culture household organisation. An economic model. In A. Whittle and P. Bickle (eds), Early Farmers. The View from Archaeology and Science, 159-80. Oxford: British Academy \& Oxford University Press 


\section{Furholt. aDNA STUDIES \& MIGRATION DISCOURSE, 3RD MILLENNIUM BC IN EUROPE}

Hafner, A. \& Suter, P.J. 2003. Das Neolithikum in der Schweiz. www.jungsteinsite.de. 27 November 2003

Hansen, M. 1986. Enkeltgravskulturens bopladsfund fra Vesthimmerland of Tibe-Området. In C. Adamsen, and K. Ebbesen (eds), Stridsøksetid i Sydskandinavien, 28691. Copenhagen: Forhistorisk Arkaologisk Institut, Kobenhavns Universitet

Hansen, K.P. 2003. Kultur und Kulturwissenschaft (3rd edn). Tübingen/Basel: Utb Gmbh

Hecht, D. 2007. Das schnurkeramische Siedlungswesen im südlichen Mitteileuropa: eine Studie zu einer vernachlässigten Fundgattung im Übergang vom Neolithikum zur Bronzezeit. Heidelberg: Universitätsbibliothek

Heyd, V. 2017. Kossinna's smile. Antiquity 356, 348-59

Hillier, B. \& Hanson, J. 1984. The Social Logic of Space. Cambridge: Cambridge University Press

Hofmann, D. 2015. What have genetics ever done for us? The implications of aDNA data for interpreting identity in Early Neolithic Central Europe. European Journal of Archaeology 18(3), 454-76

Hübner, E. 2005. Jungneolithische Gräber auf der jütischen Halbinsel. Typologische und chronologische Studien zur Einzelgrabkultur. Copenhagen: Det kongelige oldskriftselskab

Ion, A. 2017. How interdisciplinary is interdisciplinarity? Revisiting the impact of a DNA research for the archaeology of human remains. Current Swedish Archaeology 25, 177-98

Iversen, R. 2015. The Transformation of Neolithic Societies: An Eastern Danish Perspective on the 3rd Millennium BC. Højbjerg: Jutland Archaeological Society

Jacobs, J. 1991. Die Einzelgrabkultur in MecklenburgVorpommern. Schwerin: Archäologisches Landesmuseum Mecklenburg-Vorpommern

Jones, S. 1996. Discourses of identity in the interpretation of the past. In P. Graves-Brown, S. Jones, \& C. Gamble (eds), Cultural Identity and Archaeology, 62-80. London/New York: Routledge

Kleijne, J.P. 2013. A Matter of Life and Death at Mienakker (the Netherlands): late Neolithic behavioural variability in a dynamic landscape. Amersfoort: Cultural Heritage Agency of the Netherlands

Knipper, C., Mittnik, A., Massy, K., Kociumaka, C., Kucukkalipci, I., Masu, M., Wttenborn, S., Metz, S.E., Staskiewicz, A., Krause, J. \& Stockhammer, P.W. 2017. Female exogamy and gene pool diversification at the transition from the Final Neolithic to the Early Bronze Age in central Europe. Proceedings of the National Academy of Sciences 114(38), 10083-8.

Kolář, J. 2018. Archaeology of Local Interactions. Social and Spatial Aspects of the Corded Ware Communities in Moravia. Bonn: Habelt

Kossian, R. 2004. Die Untersuchungen in dem neolithischen 'Huntedorf 1' am Dümmer (Ldkr. Diepholz, Niedersachsen) in den Jahren 1938 bis 1940. Ein Zwischenbericht zum Stand der wissenschaftlichen Auswertung. In H.-J. Beier, and R. Einicke (eds), Varia neolithica III, 75-99. Weissbach: Beiträge zur Ur- und Frühgeschichte Mitteleuropas
Kossinna, G. 1919. Das Siegreiche Vordringen meiner wissenschaftlichen Anschauungen als Ergebnis meiner wissenschaftlichen Methode. Mannus 11/12, 396-404

Kristiansen, K., Allentoft, M.C., Frei, K.M., Iversen, R., Johannsen, N.N., Kroonen, G., Pospieszny, L., Price, T. D., Rasmussen, S., Sjögren, K.-G., Sikora, M. \& Willersley, E. 2017. Re-theorising mobility and the formation of culture and language among the Corded Ware Culture in Europe. Antiquity 356, 334-47

Lazaridis, I. \& Reich, D. 2017. Failure to replicate a genetic signal for sex bias in the steppe migration into Central Europe. Proceedings of the National Academy of Sciences 114, E3873-4. doi: 10.1073/pnas.1704308114

Lüning, J. 1972. Zum Kulturbegriff im Neolithikum. Praehistorische Zeitschrift 47, 145-73

Maggetti, M. \& Suter, P. 2017. Mineralogisch-petrographische und chemische Untersuchungen der Keramik. In P. Suter (ed.), Um 2700 v. Chr. Wandel und Kontinuität in den Ufersiedlungen am Bielersee, 236-9. Bern: Archäologischer Dienst des Kantons Bern

Makarewicz, C. 2013. A pastoralist manifesto: Breaking stereotypes and re-conceptualizing pastoralism in the Near Eastern Neolithic. Levant 45(2), 159-74

Malmström, H., Linderholm, A., Skoglund, P., Storå, J., Sjödin, P., Gilbert, M.T., Holmlund, G., Willerslev, E., Jakobsson, M., Lidén, K. \& Götherström, A. 2015. Ancient mitochondrial DNA from the northern fringe of the Neolithic farming expansion in Europe sheds light on the dispersion process. Philosophical Transactions of the Royal Society of London. Series B, Biological Sciences 370(1660), p. 20130373; doi: 10.1098/rstb.2013.0373

Matthias, W. 1982. Kataloge zur Mitteldeutschen Schnurkeramik T. 5. Mittleres Saalegebiet. Berlin: Deutscher Verlag der Wissenschaften

Müller, J. 2001. Soziochronologische Studien zum Jung-und Spätneolithikum im Mittelelbe-Saale-Gebiet (4100-2700 v. Chr.). Rahden/Westfalen: Leidorf

Müller, J. 2013. Kossinna, Childe and aDNA. Comments on the construction of identities. Current Swedish Archaeology 21, 35-7

Müller, J. \& Peterson, R. 2015. Ceramics and society in Northern Europe. In C. Fowler, J. Harding, and D. Hofmann (eds), The Oxford Handbook of Neolithic Europe, 573-604. Oxford: Oxford University Press

Nordqvist, K. \& Häkälä, P. 2014. Distribution of Corded Ware in the areas north of the Gulf of Finland - an update. Estonian Journal of Archaeology 18(1), 3

Olalde, I. et al. 2018. The Beaker phenomenon and the genomic transformation of northwest Europe. Nature 555(7695), 190-6

Pechtl, J. 2015. Linearbandkeramik pottery and society. In C. Fowler, J. Harding, and D. Hofmann (eds), The Oxford Handbook of Neolithic Europe, 555-72. Oxford: Oxford University Press

Prescott, C. \& Glørstad, H. 2015. Expanding 3rd millennium transformations: Norway. In M.P. Prieto Martínez and L. Salanova (eds), The Bell Beaker Transition in Europe: Mobility and local evolution during the $3 \mathrm{rd}$ millennium BC, 77-87. Oxford: Oxbow Books 
Rascovan, N., Sjögren, K.G., Kristiansen, K., Nielsen, R., Willerslev, E., Desnues, C. \& Rasmussen, S. 2018. Emergence and spread of basal lineages of Yersinia pestis during the Neolithic decline. Cell 176(1-2), 295-305; doi: 10.1016/j.cell.2018.11.005

Reich, D. 2018. Who We Are and How We Got Here: Ancient DNA and the New Science of the Human Past. New York: Pantheon

Rimantienè, R. 1992. The Neolithic of the Eastern Baltic. Journal of World Prehistory 6(1), 97-143

Robb, J. \& Harris, O.J.T. 2018. Becoming gendered in European prehistory: Was Neolithic gender fundamentally different? American Antiquity 83(1), 128-47

Roberts, B.W. \& Vander LindenM. (eds). 2011. Investigating Archaeological Cultures. New York: Springer

Salzman, E. 2004. Poselenija kultury schnurowoi keramiku na territorii Kalinigradskoi oblasti. Kalinigrad

Sarauw, T. 2007. Danish Bell Beaker pottery and flint daggers - the display of social identities? European Journal of Archaeology 11(1), 23-47

Schachner, G. 2012. Population Circulation and the Transformation of Ancient Zuni Communities. Tucson: University of Arizona Press

Schultrich, S. 2018. Das Jungneolithikum in SchleswigHolstein. Leiden: Sidestone Press

Šebela, L. 1999. The Corded Ware Culture in Moravia and in the Adjacent Part of Silesia (Catalogue). Brno: Archeologický Ústav Akademie Věd České Republiky v Brně

Shennan, S. 2000. Population, culture history, and the dynamics of culture change. Current Anthropology 41(5), 811-35

Shishlina, N.I. 2008. Reconstruction of the Bronze Age of the Caspian Steppes: Life styles and life ways of pastoral nomads. Oxford: British Archaeological Report S1876

Shishlina, N., Sevastyanov, V. \& Hedges, R.E.M. 2012. Isotope ratio study of Bronze Age samples from the Eurasian Caspian Steppes. In E. Kaiser, J. Burger, \& W. Schier (eds), Population Dynamics in Prehistory and Early History. New Approaches Using Stable Isotopes and Genetics, 177-97. Berlin/Boston: De Gruyter

Sjögren, K.-G., Price, T.D. \& Kristiansen, K. 2016. Diet and mobility in the Corded Ware of Central Europe. PLOS ONE 11(5), e0155083

Skoglund, P., Malmström, H., Raghavan, M., Storå, J., Hall, P., Willerslev, E., Gilbert, M.T., Götherström, A. \& Jakobsson, M. 2012. Origins and genetic legacy of Neolithic farmers and hunter-gatherers in Europe. Science 336(6080), 466-9
Skoglund, P., Malmström, H., Omrak, A., Raghavan, M., Valdiosera, C., Günther, T., Hall, P., Tambets, K., Parik, J., Sjögren, K.G., Apel, J., Willerslev, E., Storå, J., Götherström, A. \& Jakobsson, M. 2014. Genomic diversity and admixture differs for stone-age Scandinavian foragers and farmers. Science 344(6185), 747-50

Strahl, E. 1990. Das Endneolithikum im Elb Weser Dreieck. Hildesheim: Veröffentlichungen der urgeschichtlichen Sammlungen des Landesmuseums zu Hannover 36

Strahm, C. 1971. Die Gliederung der Schnurkeramischen Kultur in der Schweiz. Bern: Stämpfli \& Cie

Strahm, C. 2010. Endneolithische Siedlungsmuster. In I. Matuschik, and C. Strahm (eds), Vernetzungen. Aspekte siedlungsarchäologischer Forschung. Festschrift für Helmut Schlichterle zum 60. Geburtstag, 317-30. Freiburg: Lavori

Strahm, C. \& Buchvaldek, M. 1991. Die kontinentaleuropäischen Gruppen der Kultur mit Schnurkeramik. Prague: Praehistorica 19

Strien, H.-C. 2005. Familientraditionen in der bandkeramischen Siedlung bei Vaihingen/Enz. In J. Lüning, and C. Frirdich (eds), Die Bandkeramik im 21. Jahrhundert, 189-97. Rahden/Westfahlen: Leidorf

Suter, P. 2017. Um 2700 v. Chr. Wandel und Kontinuität in den Ufersiedlungen am Bielersee. Bern: Archäologischer Dienst des Kantons Bern

Vander Linden, M. 2006. Le phénomène campaniforme dans l'Europe du 3ème millénaire avant notre ère: synthèse et nouvelles perspectives. Oxford: British Archaeological Report S1470

Vander Linden, M. 2015. Bell Beaker pottery and society. In C. Fowler, J. Harding, and D. Hofmann (eds), The Oxford Handbook of Neolithic Europe, 605-20. Oxford: Oxford University Press

Vander Linden, M. 2016. Population history in third-millennium-BC Europe: assessing the contribution of genetics. World Archaeology 48(5), 714-28

Wenger, E. 1998. Communities of practice: Learning, meaning, and identity. Cambridge/New York: Cambridge University Press

Włodarczak, P. 2006. Kultura Ceramiki Sznurowej na Wyżynie Małopolskiej. Kraków: Instytut archeologii i etnologii Polskiej Akademii Nauk

Zvelebil, M. \& Pettitt, P. 2013. Biosocial archaeology of the Early Neolithic: Synthetic analyses of a human skeletal population from the LBK cemetery of Vedrovice, Czech Republic. Journal of Anthropological Archaeology 32(3), 313-29

\section{RÉSUMÉ}

Réintégration de l'archéologie: Contribution aux études d'ADN et à la cconversation sur la migration au 3ème millénaire av.J.C en Europe, de Martin Furholt

Depuis qu'une étude d'ADN a indiqué un flux génétique marqué venu de l'est en Europe centrale au 3ème millénaire av.-J.C des récits démodés, simplistes de migrations massives de populations fermées ont refait leur apparition dans les discussions archéologiques. Un modèle plus sophistiqué de migration venant des steppes fut proposé récemmemt par Kristiansen et al. En réaction à cette proposition, cet article a pour but d'apporter sa contribution à ce débat en cours en raffinant ce dernier modèle, offrant une meilleure intégration des données 


\section{Furholt. aDNA STUDIES \& MIGRATION DISCOURSE, 3RD MILLENNIUM BC IN EUROPE}

archéologiques et de la connaissance anthropologique. Nous argumentons qu'une classification polythétique du matériel archéologique en Europe centrale au 3ème millénaire révèle la présence d'un nouveau complexe de rituels d'inhumations individuelles qui transcendent les traditionnelles étiquettes de cultures. L'héritage génétique de la steppe est essentiellement lié à cette nouvelle forme d'inhumations plutôt qu'au matériel de la poterie cordée ou des peuples à vases. Ici nous argumentons qu'une vue polythétique des vestiges archéologiques suggère des histoires plus complexes de migration, mélange de population et interaction que ne le laissait supposer des modèles plus anciens et des façons de mieux intégrer des études détaillées du matériel archéologique avec une exploration plus appprofondie des modèles anthropologiques de mobilité et de composition de groupes sociaux et nous explorons les données biologiques moléculaires.

\section{ZUSSAMENFASSUNG}

Die Re-Integration der Archäologie: Ein Beitrag zu aDNA-Untersuchungen und zum Diskurs zu Migrationen im 3. Jahrtausend BC in Europa, von Martin Furbolt

Mit den Hinweisen aktueller aDNA-Untersuchungen auf einen markanten Genfluss von Ost- nach Mitteleuropa im 3. Jahrtausend erstarken in den archäologischen Untersuchungen erneut veraltete und vereinfachende Narrative von massiven Migrationen geschlossener Bevölkerungsgruppen. Ein anspruchsvolleres Modell von Migrationen aus der Steppe wurde jüngst von Kristiansen et al. vorgelegt. Als Reaktion auf diesen Vorschlag möchte der vorliegende Aufsatz einen Beitrag zu dieser fortdauernden Debatte leisten, indem hier letzteres Modell verfeinert wird durch eine bessere Integration von archäologischen Daten und anthropologischem Wissen. Es wird argumentiert, dass eine polythetische Klassifikation des archäologischen Materials aus Mitteleuropa im 3. Jahrtausend das Vorhandensein eines neuen Komplexes von EinzelgrabBestattungsritualen aufzeigt, der die traditionellen Kulturbezeichnungen transzendiert. Die genetische SteppenSignatur ist vor allem mit diesem neuen Bestattungstyp verbunden und weniger mit schnurkeramischem oder Glockenbecher-Material. Eine polythetische Betrachtung der archäologischen Quellen, so wird hier argumentiert, lässt kompliziertere historische Abläufe von Migration, Mischung und Interaktion von Populationen erkennen als die bisherigen Modelle. Möglichkeiten einer besseren Integration von detaillierten Untersuchungen archäologischen Materials mit einer tiefergehenden Auswertung anthropologischer Modelle von Mobilität und sozialer Gruppenzusammensetzung und mit den molekularbiologischen Daten werden ergründet.

\section{RESUMEN}

Re-integrando la arqueología: una contribución de los estudios de ADN antiguo y el discurso sobre las migraciones en Europa durante el III milenio BC, por Martin Furbolt

Desde que los estudios de ADN antiguo sugirieron un marcado influjo genético desde el Este hacia Centroeuropa en el III milenio BC, se han propuesto anticuadas y simplistas narrativas sobre migraciones masivas de poblaciones cerradas en las discusiones arqueológicas. Un modelo más sofisticado de migración de las estepas ha sido recientemente propuesto por Kristiansen et al. Como reacción a esta propuesta, este artículo pretende contribuir al actual debate definiendo el último modelo, integrando de manera más apropiada los datos arqueológicos y el conocimiento antropológico. Se argumenta que una clasificación politética del material arqueológico en Centroeuropa en el III milenio BC revela la presencia de un complejo nuevo, caracterizado por un ritual funerario individual que trasciende las características tradicionales de este complejo cultural. El ancestro genético estepario está principalmente relacionado con este nuevo tipo de enterramientos, más que con la cerámica Corded Ware o con los materiales campaniformes. En este artículo se argumenta que una visión politética de la evidencia arqueológica sugiere historias más complicadas de migración, mezclas poblacionales e interacciones que las asumidas por modelos anteriores, y permite una mayor integración de los detallados estudios de materiales arqueológicos con una profunda exploración de los modelos antropológicos de movilidad y composición social del grupo y la exploración de los datos de biología molecular. 